\title{
ESTABLISHMENT OF GENDER-INCLUSIVE COCONUT-BASED MULTI-STOREY FARM MODEL IN BUKIDNON, PHILIPPINES
}

\author{
Vences C. Valleser ${ }^{1 *}$, Agripina R. Aradilla ${ }^{2}$, Ma. Stella M. Paulican ${ }^{2}$ \\ ${ }^{1}$ Department of Horticulture, College of Agriculture, Central Mindanao University, Musuan, Maramag, \\ Bukidnon, 8710 Philippines \\ ${ }^{2}$ Department of Agronomy and Plant Breeding, College of Agriculture, Central Mindanao University, Musuan, \\ Maramag, Bukidnon, 8710 Philippines \\ *corresponding author: vcvalleser@gmail.com
}

\begin{abstract}
Coconut palms are ideal for diversified (i.e. multi-storey cropping) production system across stages of growth and development. However, local information on the role of women in coconut-based multi-storey cropping is not available. Hence, this study was conceptualized to evaluate the growth of intercrops to coconut at initial vegetative growth with a woman as maintainer in a multi-storey farm in Bukidnon, Philippines. Land resource utilization in newly established coconut plantation was maximized by planting high-value intercrops such as pineapple, cacao and vegetables and were found to have no adverse effects on the growth. Eggplant as intercrop produced the highest gross income for a one-hectare non-bearing stage of coconut. On the other hand, the role of women in the establishment of a coconut-based multi-storey farm was found to be essential in all aspects of intercultural management practices, except foliar application of synthetic fertilizers and pesticides. The results could serve as guide to policy makers in establishing a gender-inclusive coconut-based multi-storey farm.
\end{abstract}

Keywords: coconut-based farm, gender-inclusive farm, multi-storey, techno-demo farm

http://dx.doi.org/10.21776/ub.agrise.2020.020.1.8

Received 8 August 2019

Accepted 17 December 2019

Available online 31 January 2020

\section{INTRODUCTION}

Bukidnon is known as the "fruit basket" of Northern Mindanao, Philippines and is the largest contributor to the regional agricultural economy. In its early history of agriculture, the province had already been identified as suitable for large scale production of food for export (Lao, 1992). Bukidnon has a total land area of 1,049,859 hectares of which 669,529.25 hectares are classified as timberland and the remaining 380,332.75 hectares is classified as alienable and disposable (www.bukidnon.gov.ph), and $92 \%$ of which is utilized for agricultural production. In 2017, Bukidnon had a total population of 1,415,226 comprising 736,548 males and 678,678 females (Philippine Statistics Authority [PSA], 2018).
In terms of physical distribution of agricultural areas, sugarcane lands dominate the landscape of Bukidnon followed by corn lands, pineapple and irrigated rice (www.bukidnon.gov.ph) which are mostly cultivated as monocropping or sole cropping. Monocropping is the cultivation of only one crop in an area. This farming practice is inferior to diversified cropping system specifically on environmental conservation.

Meanwhile, the Philippines is the world's largest coconut producer and coconut oil exporter. Javier (2013) presented at least four good reasons why coconut is and shall remain the dominant industrial perennial crop in the Philippine countryside. One of these reasons is the opportunity to make full use of the sunlight filtering between the trees by planting intercrops, both annuals and perennials. Intensive 
multiple canopy farming create more employment, more food resulting to lower food prices for everyone, and provide additional income to coconut farmers often far exceeding the revenue from coconut itself (Javier, 2013).

To maximize land utilization, coconut can be intercropped with vegetables (Philippine Coconut Authority [PCA], 2006a), cereal such as corn (PCA, 2004a), cacao (PCA, 2007), coffee (PCA, 2006c), fruit crops (PCA, 2004b), root crops (PCA, 2006b) and even gemilina (PCA, 2004c). Multi-storey cropping system can also be employed (PCA, 2005; Relacion, 2017; Segarino, 2017; Tabios, 2017) in established coconut plantations. This system is characterized by randomly mixing various species that create at least two layers of canopy. It mimics the structure of a tropical rainforest with its attendant advantages. The upper canopy is composed of light-demanding species, while the understorey is made up of shade-tolerant species (Philippine Council for Aquatic, Agriculture, Forestry and Natural Resources Research and Development [PCAARRD], 2018).

In the Philippines, diversified as well as multistorey cropping have been adopted in several regions. However, there are no local information on the role of women in coconut-based multi-storey cropping. A coconut-based multi-storey technodemo farm model was established at the University Research, Development and Extension Grounds (RDE), Central Mindanao University to: 1) maximize land resource grown to coconuts by planting intercrops such as fruit crops, vegetables and plantation crops; and 2) evaluate the role of woman-worker in the establishment of a coconutbased multi-storey farm.

\section{RESEARCH METHODS}

\section{Site Selection and Establishment of Coconut Plantation}

The establishment of coconut-based multi-storey farm model at the RDE Complex (Figure 1), Central Mindanao University (CMU) started on October 1, 2017. The area was previously planted with annual crops such as vegetables and cereals. The farm layout (Figure 2) was prepared based on the actual field topography. No-tillage cropping was employed in the area.

Digging of holes $(50 \mathrm{~cm}$ depth and $50 \mathrm{~cm}$ diameter) for coconut were manually done using a digger. One kg of complete (14-14-14) fertilizer was applied per hole one week before transplanting. Tall coconut variety was then planted on October 20, 2017 at a distance of $8 \mathrm{~m} \times 8 \mathrm{~m}$ in square planting system.

\section{Management of Intercrops}

Light transmission and suitable intercrops in coconut multi-storey cropping system (Table 1) were considered. Annual crops such as eggplants, lady's finger, sweet potato, peanut, chili, cowpea and yam bean were intercropped to coconut on December 2017. Moreover, cacao seedlings (National Seed Industry Council registered) were also intercropped to coconuts on January 2018. Suckers of desert banana (Latundan and Lagkitan) and pineapple (mixed varieties) were also transplanted in the area on February 2018. Cultural management practices, depending on the intercrops, were employed in that said coconut-based multistorey farm.

\section{Data Gathered}

Plant growth

Plant growth data of coconuts and some intercrops were gathered one year after planting coconuts. Coconut, cacao, banana and pineapple served as data plants at ten samples each species. These were randomly taken from among the plants across the plantation.

1. Plant height - This parameter was measured from the ground level or base of plant to the tip of longest leaf using a pre-calibrated measuring stick. Mean plant height was determined using the formula:

$$
\begin{aligned}
& \text { Plant } \\
& \text { height }
\end{aligned}=\frac{\sum \text { plant height }(\mathrm{cm})}{10}
$$

2. Stem diameter - This parameter was measured using a pre-calibrated caliper and the method of measurement vary depending on the plant species. For coconut, measurement was done at $30 \mathrm{~cm}$ of the stem above the ground level. For banana, the diameter of pseudostem was at one meter from the ground level. For cacao, it was measured at the graft union. Mean stem diameter was measured using the formula:

$$
\begin{gathered}
\text { Stem } \\
\text { diameter }
\end{gathered}=\frac{\sum \text { stem diameter }(\mathrm{cm})}{10}
$$

3. Canopy spread - The radius of the longest canopy spread from the stem was measured using a measuring stick and mean canopy spread was obtained using the formula:

$$
\begin{aligned}
& \text { Canopy } \\
& \text { spread }
\end{aligned}=\frac{\sum \text { canopy spread }(\mathrm{cm})}{10}
$$


4. Plant mass - This parameter was gathered for pineapple crop only. Three randomly selected pineapple plants were uprooted and weighed using a pre-calibrated weighing scale. The mass of these plants served as reference in estimating the mass of ten sample plants. Mean plant mass was computed using the formula:

$$
\text { Plant } \quad=\frac{\sum \text { plant mass }(\mathrm{kg})}{10}
$$

5. Number of leaves - This parameter was gathered for cacao crop only. Functional leaves per plant were manually counted and recorded. Mean number of leaves was computed using the formula:

$$
\begin{aligned}
& \text { Number } \\
& \text { leaves }
\end{aligned} \quad \text { of }=\frac{\sum \text { number of leaves }}{10}
$$

6. Number of flowers - This parameter was gathered for cacao crop only. Flowers developed per plant were manually counted and recorded. Mean number of flowers was computed using the formula:

$$
\begin{aligned}
& \text { Number of } \\
& \text { flowers }
\end{aligned}=\frac{\sum \text { number of flowers }}{10}
$$

7. Number of suckers - This parameter was gathered for banana crop only. Suckers developed per plant were manually counted and recorded. Mean number of suckers was computed using the formula:

$$
\begin{aligned}
& \text { Number of } \\
& \text { suckers }
\end{aligned}=\frac{\sum \text { number of suckers }}{10}
$$

Mean standard deviation of the data gathered were determined using the Statistical Package for Social Sciences 14.0 for Windows Evaluation.

\section{Yield}

For annual crops such as eggplants, lady's fingers, sweet potatoes, peanuts, chili, cowpeas and yam beans, the economic yield was gathered instead of plant growth data. Yield for intercrop was expressed in tons $\mathrm{ha}^{-1}$ and computed using the formula:

Yield $=\frac{\text { Weight of economic part of the plant }(\mathrm{kg})}{\text { Area }(\mathrm{m} 2)} \times \frac{10000 \mathrm{~m} 2}{1 \mathrm{ha}} \times \frac{1 \text { ton }}{1000 \mathrm{~kg}}$

\section{The role of woman-worker}

Activities conducted during the establishment phase of the coconut-based multi-storey farm were documented according to: 1) activities that can be performed by a female worker alone, 2) activities that require the assistance of a male worker; and 3) activities that cannot be performed by a female worker.

Figure 1. Map showing the location of the coconut-based multi-storey techno-demo farm model at Central Mindanao University

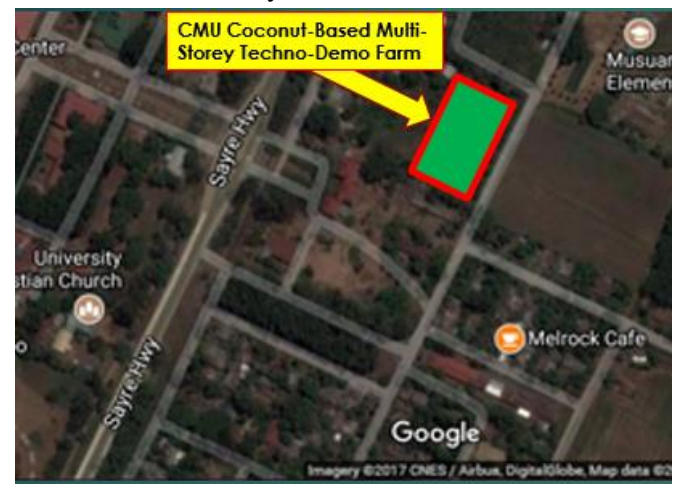

Source: Google Map

Figure 2. Farm lay-out of the coconut-based multistorey farm at Central Mindanao University, Philippines

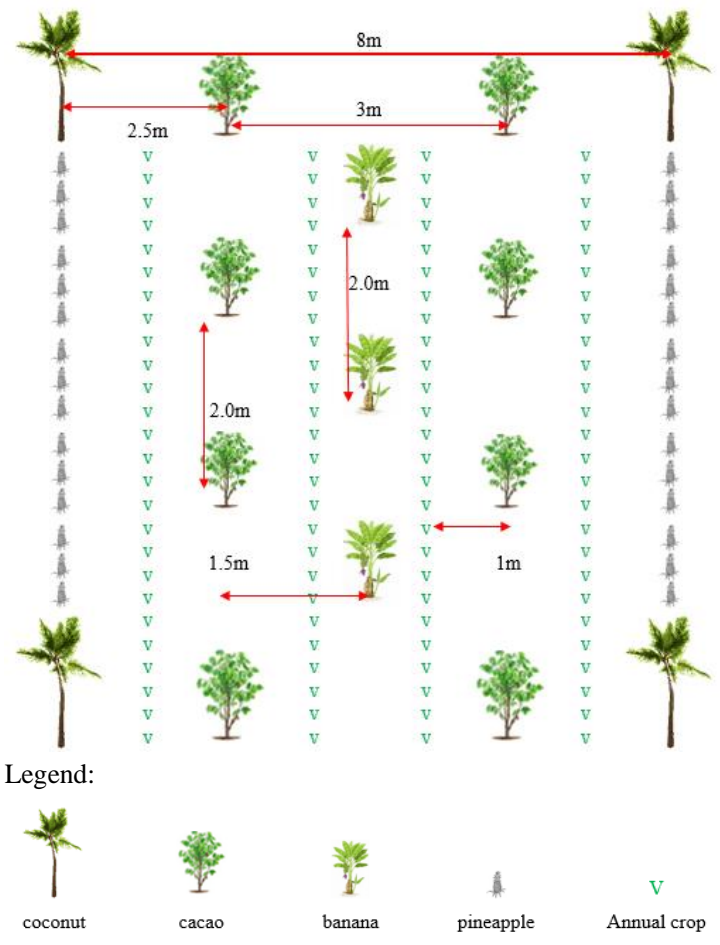


Table 1. Growth duration and productivity periods, levels of sunlight transmission and suitable intercrops (Magat, 2003)

\begin{tabular}{|c|c|c|}
\hline $\begin{array}{l}\text { Phase } \\
\text { (Stage) }\end{array}$ & Duration & Level of available sunlight/highly suitable intercrops \\
\hline I & $\begin{array}{l}\text { Field planting to } \\
6 \text { years }\end{array}$ & $\begin{array}{l}\text { High to moderate/highly suitable intercrops: } \\
\text { Cereals - corn, upland rice } \\
\text { Legumes - cowpea, peanut, mungbean, sitao, beans } \\
\text { Root crops - sweet potato, gabi } \\
\text { Fruit crops - pineapple, citrus, watermelon, papaya, banana Vegetables - } \\
\text { tomato, cabbage, eggplant, sweet pepper, hot pepper, okra }\end{array}$ \\
\hline II & $7-25$ years $^{1}$ & $\begin{array}{l}\text { Moderate to low/highly suitable crops: } \\
\text { Black pepper, cacao, coffee, tomato, vanilla, ginger, lanzones, rambutan, } \\
\text { durian, mangosteen, gmelina tree (for wood and lumber) }\end{array}$ \\
\hline III & $26-60$ years & $\begin{array}{l}\text { High/highly suitable crops }{ }^{2} \text { : } \\
\text { Cereals - corn, upland rice } \\
\text { Legumes - peanut, mungbean, cowpea, beans } \\
\text { Vegetables - tomato, eggplant, cabbage, sweet pepper, hot pepper, okra, ginger } \\
\text { Root crops - sweet potato, gabi, cassava, ubi } \\
\text { Beverage crops - coffee, cacao } \\
\text { Fruit crops - lanzones, rambutan, durian, mangosteen, citrus (pomelo, } \\
\text { calamansi) } \\
\text { Wood and lumber tree - gmelina } \\
\text { Fiber crops - ramie, abaca }\end{array}$ \\
\hline
\end{tabular}

$\overline{{ }^{1} \text { Except tomato, usually the suitable crops indicated requires lower sunlight or moderate shade during the pre-bearing stage of }}$ the crops, thus field-establishment is best done during this stage.

${ }^{2}$ Should more sunlight transmission to intercrops needed for normal growth and high yields, coconut leaf pruning (CLP) technique (removal of older lower leaves of the crown, maintaining the upper 20-23 leaves); allowing 0.5 meter of cut frond attached to the trunk.

\section{RESULTS AND DISCUSSION}

\section{Growth of Coconut and Intercrops Coconut}

Plant height of coconut $(2.21 \mathrm{~m})$ as shown on Table 2 was relatively taller compared to the standard norm value $(1.30 \mathrm{~m})$ at one year after transplanting. Coconut varieties are generally classified as "Tall" and "Dwarf'. In this study, tall variety was used. Tall coconut variety has an average height increment of one meter annually. On the other hand, stem diameter was doubled at one year after planting. Canopy spread $(1.06 \mathrm{~m})$ implies that intercrops can be planted at $1.0-1.5 \mathrm{~m}$ from the coconut plants. Results further suggest that coconut at early stage of growth is ideal for diversified or multiple cropping system. At 0-6 years old coconut plantation, the level of available sunlight ranges from moderate to high (Magat, 2003), and sunlight loving crops can therefore be intercropped to maximize land area utilization.

\section{Banana}

Banana is the number one fruit crop produced in the Philippines. Hence, it is one of the fruits intercropped to coconut. For dessert bananas, solar radiation should be as high as possible for best growth and yield (Paull and Duarte, 2011). In this study, banana plants exhibited better growth compared to those grown in conventional plantation as shown on Table 2. In the model farm, among the crops planted including coconut, bananas were the tallest and occupied the top level of the storey (Figure 3). The result indicates good solar radiation at ground level as supported also by the number of suckers developed in bananas $(\approx 6.0$ suckers per plant). Paull and Duarte (2011) mentioned that less radiation at ground level will lead to reduced sucker production of banana plants. 


\section{Cacao}

Cacao is a tree crop highly suitable in different cropping systems. It is considered as a shade-loving crop. In this study, transplanting of cacao seedlings was done without shade crops. However, growth data (Table 2) implies that cacao plants performed well even without shade at early stage of growth. Flowering was already observed as early as 9 months after transplanting. The better growth could be attributed by the types of varieties used in this study. R. Cena (personal communication, October $10,2018)$ stated that NSIC recommended cacao clones such as UF 18, BR 25, PBC 123, K1, K2, K9, USM CH-1, USM CH-2 are high-yielding and could withstand unfavorable condition such as higher light intensity.

\section{Pineapple}

In the Philippines, pineapple production in January to March 2016 reached 591.25 thousand metric tons (Philippine Statistics Authority, 2016a) of which majority of the produced are being exported to other countries. Pineapple export industry in the Philippines is concentrated in the province of Bukidnon. Hence, pineapple was one of the chosen intercrops for the coconut-based multi-storey farm model in CMU, Bukidnon, Philippines. It is a sunlight loving crop but can tolerate shading.

In this study, pineapple plants at 8 months after planting (MAP) had an average height of $0.84 \mathrm{~m}$ and mass of $1.84 \mathrm{~kg}$. Plant mass is relatively higher compared to the standard norm value $(1.32 \mathrm{~kg})$. In commercial pineapple production, plant mass is usually used to forecast fruit size distribution. Pineapple plant mass of at least $2.0 \mathrm{~kg}$ at $11.5 \mathrm{MAP}$ is minimum for flower induction to produce marketable fruits ( $\geq 1 \mathrm{~kg}$ ). Hepton (2003) stated that correlation between plant mass and fruit mass can be as low as 0.4 in areas with warm nights and fast growth rates and can exceed 1.0 where irradiance is high and night temperatures are cool. Moreover, higher yield of pineapple can be attained using higher density planting (75,000 plants ha-1) as reported by Valleser (2019) which makes it compatible to diversified cropping such as multistorey farm.

\section{Yield of Annual Intercrops}

The harvesting of annual intercrops such as eggplants and lady's fingers started on March 2018 to September 2018. Sweet potato, peanut, chili and yam bean were harvested on June 2018. Yield data expressed in tons ha- 1 are presented on Table 3 . Yield per hectare of annual intercrops in a multistorey cropping is found to be inferior compared to conventional cropping system. The low yield is reasonable due to the reduced area planted to intercrops in multi-storey cropping. Further, these annual crops are warm season crops that may not tolerate partial shading.

Among the annual intercrops grown, eggplants had the highest yield and had the highest potential gross income of $\mathrm{PhP}$ 7,589.00 per month. The income from the intercrops could augment income of coconut farmers in the Philippines. According to Javier (2013), the poorest farmers in the country are the coconut growers with an average monthly income of $\mathrm{PhP}$ 1,500.00. Bukidnon is one of the poorest provinces in the Philippines (PSA, 2018). Hence, multi-storey cropping is advantageous to increase monthly income of coconut farmers in the province of Bukidnon, Philippines and the neighboring communities.

\section{Role of Woman-Worker on the Establishment Phase of Coconut-Based Multi-Storey Farm}

Table 4 shows the activities that can be performed by a woman-worker in the establishment of a coconut-based multi-sorey farm. The accomplishments of a female worker in the establishment of the CMU multi-storey technodemo farm suggests that a woman can perform all farm activities except clearing of the area and applications of pesticides and synthetic fertilizers as foliar spray that require the assistance of men. Results suggest not to be dependent in pesticide and synthetic fertilizers foliar applications as these activities would partially displace if not at all the women in coconut-based multi-storey farm.

Pesticides harm humans especially women. Fetuses, infants, growing children, pregnant and nursing mothers, and women of childbearing age are most at risk for adverse health outcomes from exposure to pesticides (The Center for Ecogenetics and Environmental Health, 2013). Results of this study suggest that coconut-based multi-storey cropping should not be dependent on the use of synthetic pesticides to control pests as this activity harm humans especially women aside from being an environmental hazard. RA 10068 or the Organic Agriculture Act of the Philippines (2010) can be 
promoted by policy makers to propagate, develop further and implement the practice of organic agriculture in the country. This will cumulatively alleviate soil condition and enrich soil fertility, increase farm productivity, reduce pollution and destruction of the environment, prevent the depletion of natural resources, further protect the health of farmers, consumers, and the general public, and save on imported farm inputs.

Table 2. Growth of coconut and its intercrops at the early establishment of a coconut-based multi-storey farm

\begin{tabular}{|c|c|c|c|c|c|c|}
\hline $\begin{array}{c}\text { Crop } \\
\text { component }\end{array}$ & $\begin{array}{c}\text { Plant growth } \\
\text { parameter, plant } \\
\text { age }\end{array}$ & $\begin{array}{l}\text { Initial } \\
\text { data at } \\
\text { planting }\end{array}$ & $\begin{array}{l}\text { Recent } \\
\text { growth data }\end{array}$ & $\begin{array}{l}\text { Growth } \\
\text { increment } \\
(\%)^{*}\end{array}$ & $\begin{array}{l}\text { Norm value } \\
\text { (Conventional } \\
\text { farming) }\end{array}$ & $\begin{array}{c}\text { Variation } \\
\text { against the } \\
\text { norm value } \\
(\%) * *\end{array}$ \\
\hline \multirow[t]{3}{*}{$\begin{array}{l}\text { Coconut } \\
\text { (tall) }\end{array}$} & $\begin{array}{l}\text { Plant height }(\mathrm{m}) \text {, } \\
12 \text { MAP }\end{array}$ & 0.30 & $2.21 \pm 0.25$ & 637 & 1.30 & +70.00 \\
\hline & $\begin{array}{l}\text { Stem diameter } \\
(\mathrm{cm}), 12 \text { MAP }\end{array}$ & 3.00 & $8.55 \pm 0.90$ & 185 & - & NA \\
\hline & $\begin{array}{l}\text { Canopy spread } \\
(\mathrm{m}), 12 \text { MAP }\end{array}$ & 0.30 & $1.06 \pm 0.24$ & 253 & - & NA \\
\hline \multirow{5}{*}{$\begin{array}{l}\text { Cacao } \\
\text { (mixed } \\
\text { varieties) }\end{array}$} & $\begin{array}{l}\text { Plant height }(\mathrm{m}) \text {, } \\
9 \text { MAP }\end{array}$ & 0.35 & $1.16 \pm 0.24$ & 231 & - & NA \\
\hline & $\begin{array}{l}\text { Stem diameter } \\
(\mathrm{cm}), 9 \text { MAP }\end{array}$ & 1.00 & $3.85 \pm 0.53$ & 285 & - & NA \\
\hline & $\begin{array}{l}\text { No. of leaves, } 9 \\
\text { MAP }\end{array}$ & 10.00 & $64.60 \pm 18.89$ & 546 & - & NA \\
\hline & $\begin{array}{l}\text { Canopy spread } \\
\text { radius }(\mathrm{m}), 9 \\
\text { MAP }\end{array}$ & 0.05 & $0.645 \pm 0.11$ & 119 & - & NA \\
\hline & $\begin{array}{l}\text { No. of flowers } \\
\text { per plant, } 9 \text { MAP }\end{array}$ & 0.00 & $0.80 \pm 2.53$ & NA & - & NA \\
\hline \multirow{4}{*}{$\begin{array}{l}\text { Banana } \\
\text { (Latundan } \\
\text { and } \\
\text { Lagkitan) }\end{array}$} & $\begin{array}{l}\text { Plant height (m), } \\
8 \text { MAP }\end{array}$ & 0.50 & $4.36 \pm 0.65$ & 772 & 3.941 & +11.00 \\
\hline & $\begin{array}{l}\text { Pseudostem } \\
\text { diameter }(\mathrm{cm}), 8 \\
\text { MAP }\end{array}$ & 5.00 & $19.90 \pm 2.28$ & 298 & 10.001 & +99.00 \\
\hline & $\begin{array}{l}\text { Canopy spread } \\
\text { radius }(\mathrm{m}), 8 \\
\text { MAP }\end{array}$ & 0.20 & $2.43 \pm 0.42$ & 1112 & - & NA \\
\hline & $\begin{array}{l}\text { No. of suckers, } 8 \\
\text { MAP }\end{array}$ & 0.00 & $5.60 \pm 0.97$ & NA & - & NA \\
\hline \multirow[t]{3}{*}{ Pineapple } & $\begin{array}{l}\text { Plant height }(\mathrm{m}) \text {, } \\
8 \text { MAP }\end{array}$ & 0.30 & $0.84 \pm 0.10$ & 180 & - & NA \\
\hline & $\begin{array}{l}\text { Plant mass }(\mathrm{kg}), 8 \\
\text { MAP }\end{array}$ & 0.33 & $1.84 \pm 0.63$ & 467 & 1.322 & +39.40 \\
\hline & $\begin{array}{l}\text { Canopy spread } \\
\text { radius }(\mathrm{m}), 8 \\
\text { MAP }\end{array}$ & 0.01 & $0.67 \pm 0.15$ & 6600 & - & NA \\
\hline
\end{tabular}

\footnotetext{
*- recent growth data-initial data at planting x 100 recent growth data

**- norm value (conventional farming) x 100 recent growth data

${ }^{1}$ dela Cruz et al., 2008

${ }^{2}$ T. Castro, personal communication, November 8, 2018
} 
Table 3. Yield and estimated gross income from annual intercrops

\begin{tabular}{|c|c|c|c|c|c|c|c|}
\hline \multirow[b]{2}{*}{ Parameter } & \multicolumn{7}{|c|}{ Annual intercrop } \\
\hline & Eggplants & $\begin{array}{l}\text { Lady's } \\
\text { fingers }\end{array}$ & $\begin{array}{l}\text { Sweet } \\
\text { potatoes }\end{array}$ & Peanuts & Chili & Cowpeas & $\begin{array}{l}\text { Yam } \\
\text { beans }\end{array}$ \\
\hline Yield (tons ha-1) & 6.83 & 6.50 & 0.75 & 0.38 & 0.19 & 0.38 & 0.75 \\
\hline Months grown & 9 & 9 & 3 & 4 & 4 & 4 & 4 \\
\hline $\begin{array}{l}\text { Number of cropping } \\
\text { cycle }\end{array}$ & 1 & 2 & 1 & 1 & 1 & 1 & 1 \\
\hline $\begin{array}{l}\text { Farm gate price } \mathrm{kg}^{-1} \\
(\mathrm{PhP})^{*}\end{array}$ & 15 & 5 & 10 & 50 & 100 & 50 & 15 \\
\hline Monthly income (PhP) & 7,589 & 3,611 & 2,500 & 4,750 & 4,750 & 4,750 & 3,750 \\
\hline $\begin{array}{l}\text { Average yield (tons } \text { ha- }^{1} \text { ) } \\
\text { per cropping cycle (sole } \\
\text { crop) }\end{array}$ & $11.08 * *$ & $12-15^{* * *}$ & $6.24 * *$ & $1.64 * *$ & - & - & - \\
\hline $\begin{array}{l}\left.\text { Yield (tons ha }{ }^{-1}\right) \\
\text { difference }\end{array}$ & 4.25 & - & 5.49 & 1.26 & - & - & - \\
\hline
\end{tabular}

*- selling price at local market

**. PSA (2016b)

***- PCAARRD (n.d.)

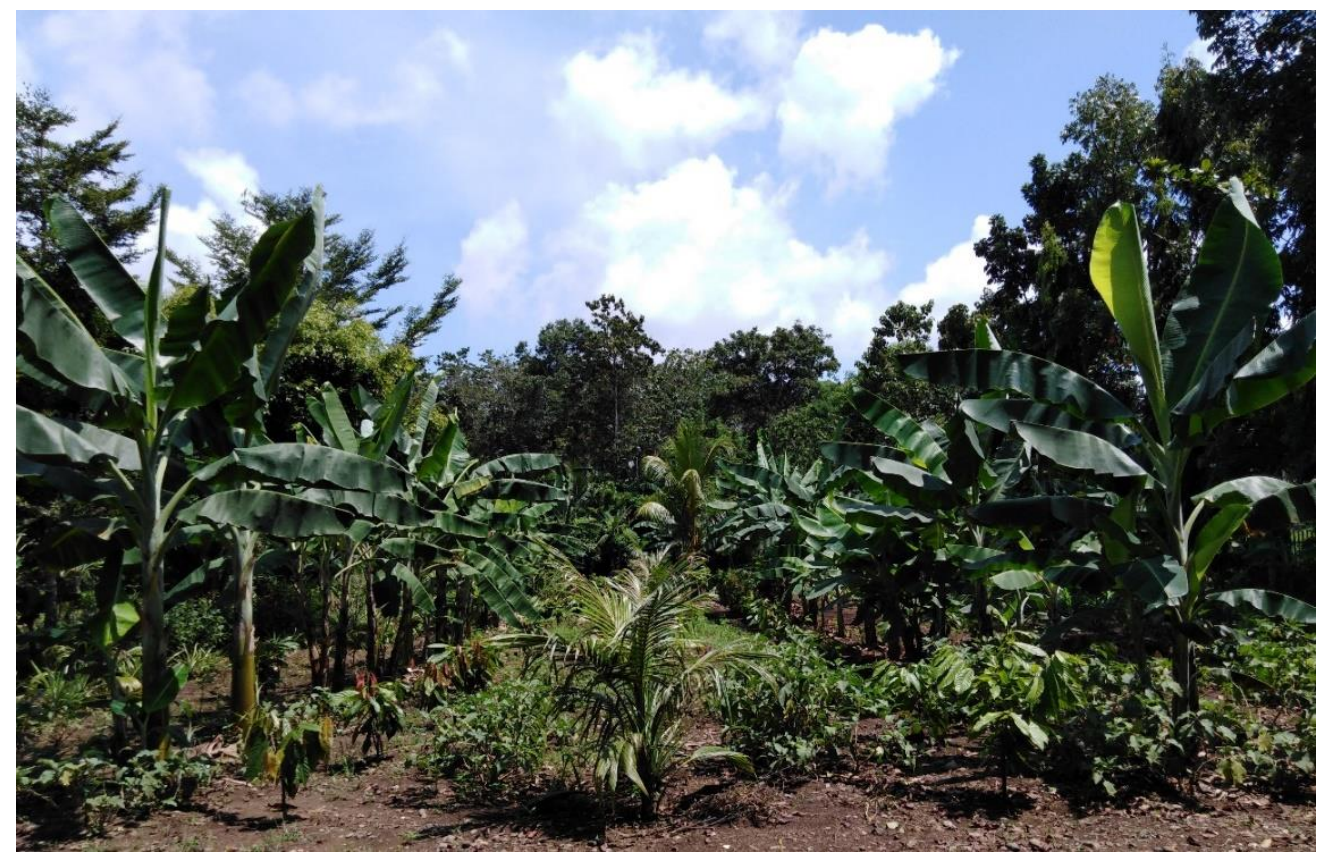

Figure 3. Establishment phase of CMU coconut-based multi-strorey techno-demo farm model showing the initial levels of crop storey (banana as the tallest), photo was taken on September 26, 2018

Table 4. Role of woman-worker in the establishment of the coconut-based multi-storey cropping system

\begin{tabular}{|c|c|}
\hline Activity/task & Role of women \\
\hline \multicolumn{2}{|l|}{ I. Coconut plantation establishment } \\
\hline$\circ \quad$ Clearing of the area & $+/-$ \\
\hline ○ Digging holes & + \\
\hline$\circ$ Hauling of planting materials & + \\
\hline ○ Basal fertilizer application & + \\
\hline
\end{tabular}




\begin{tabular}{|c|c|c|}
\hline \multicolumn{2}{|r|}{ Activity/task } & \multirow{2}{*}{$\begin{array}{c}\text { Role of women } \\
+\end{array}$} \\
\hline 0 & Planting & \\
\hline o & Round weeding, manual weeding & + \\
\hline O & Herbicide application (as needed) & -- \\
\hline ○ & Fertilizer application & + \\
\hline ○ & Spraying pesticide (as needed) & -- \\
\hline ○ & Irrigation & + \\
\hline \multicolumn{3}{|c|}{ II. Intercrop establishment } \\
\hline \multicolumn{3}{|c|}{ a. Papaya } \\
\hline ○ & Seed germination & + \\
\hline o & Sowing of seeds & + \\
\hline ○ & Seedling management & + \\
\hline ○ & Digging holes & + \\
\hline ○ & Basal fertilizer application & + \\
\hline o & Planting & + \\
\hline ○ & Round weeding, manual weeding & + \\
\hline ○ & Fertilizer application & + \\
\hline ○ & Spraying pesticide (if necessary) & -- \\
\hline o & D-leafing & + \\
\hline ○ & Irrigation & + \\
\hline ○ & Harvesting & + \\
\hline \multicolumn{3}{|c|}{ b. Cacao } \\
\hline ○ & Seed germination & + \\
\hline o & Sowing of seeds & + \\
\hline ○ & Seedling management & + \\
\hline ○ & Digging holes & + \\
\hline ○ & Basal fertilizer application & + \\
\hline ○ & Planting & + \\
\hline ○ & Round weeding, manual weeding & + \\
\hline o & Fertilizer application & + \\
\hline ○ & Spraying pesticide (if necessary) & -- \\
\hline o & Pruning & + \\
\hline ○ & Mulching & + \\
\hline ○ & Irrigation & + \\
\hline \multicolumn{3}{|c|}{ c. Banana } \\
\hline o & Planting material collection & + \\
\hline ○ & Digging holes & + \\
\hline ○ & Transplanting & + \\
\hline ○ & Round weeding, manual weeding & + \\
\hline o & Fertilizer application & + \\
\hline ○ & Spraying pesticide (if necessary) & -- \\
\hline o & D-leafing & + \\
\hline O & Irrigation & + \\
\hline \multicolumn{3}{|c|}{ d. Pineapple } \\
\hline o & Planting material collection & + \\
\hline ○ & Planting material classification & + \\
\hline ○ & Planting material fungicide treatment & + \\
\hline ○ & Planting & + \\
\hline ○ & Manual weeding & + \\
\hline O & Fertilizer application (dry form) & + \\
\hline ○ & Fertilizer application (foliar form) & -- \\
\hline ○ & Irrigation & + \\
\hline \multicolumn{3}{|c|}{ e. High-valued annual crops } \\
\hline ○ & Seed germination & + \\
\hline O & Sowing of seeds/Planting & + \\
\hline ○ & Seedling management & + \\
\hline
\end{tabular}




\begin{tabular}{rlc}
\hline \hline \multicolumn{1}{c}{ Activity/task } & Role of women \\
\hline$\circ$ & Manual weeding & + \\
$\circ$ & Fertilizer application & -- \\
$\circ$ & Spraying pesticide (if necessary) & + \\
$\circ$ & Fruit bagging (if necessary) & + \\
$\bigcirc$ & Irrigation & + \\
$\circ$ & Harvesting and postharvest management & \\
\hline+ able to perform; -- unable to perform; +/- able to perform but need assistance from men
\end{tabular}

\section{CONCLUSIONS AND RECOMMENDATIONS}

In a multi-storey cropping system at the initial stage of establishment, the growth of coconut, banana, cacao and pineapple are not undesirably affected. Annual intercrop such as eggplant showed to have the highest monthly income to coconut farmers. On the other hand, a woman-worker can perform all activities involved during the establishment of a multi-storey farm, except for foliar applications of pesticides and fertilizers, which can only be done by men. Moreover, role of a woman-worker employed in the farm could also be obtained, particularly postharvest operations of coconut, banana, cacao and pineapple in the said multi-storey farm.

\section{REFERENCES}

dela Cruz, F.S. Jr., Gueco, L.S., Damasco, O.P. et al. (2008). Farmers' handbook on introduced and local banana cultivars in the Philippines. Bioversity International, $67 \mathrm{pp}$.

Hepton, A. (2003). Cultural system. In D. P. Bartholomew, R. E. Paull and K. G. Rohrbach (Eds.), The pineapple botany, production and uses (pp. 109-142). London, UK: CABI Publishing.

Javier, E.Q. (2013). Modernization of the coconut industry. National Academy of Science and Technology, 8:1-6.

Lao, M.M. (1992). Bukidnon in historical perspective 1946-1985. Musuan, Bukidnon, Philippines: Central Mindanao University.

Magat, S.S. (2003). Pointers in practical coconutbased farming systems (CBFS). Retrieved June 9, 2017, from: http://www.pca.da.gov.ph/coconutrde/ images/gen10.pdf.

Paull, R.E. and O. Duarte. (2011). Banana and plantain: Tropical fruits. (2nd ed.), 1. (pp 185-220). Wallingford, UK: CABI Publishing.

Philippine Coconut Authority. (2004a). Coconut intercropping guide no. 1: coconut-cereal (corn) cropping model. Davao City, Philippines: Philippine Coconut Authority.

Philippine Coconut Authority. (2004b). Coconut intercropping guide no. 2: coconut-fruit crop (banana) cropping model. Davao City, Philippines: Philippine Coconut Authority.

Philippine Coconut Authority. (2004c). A coconutbased cropping system: coconut+gemilina cropping system. Davao City, Philippines: Philippine Coconut Authority.

Philippine Coconut Authority. (2005). Coconut intercropping guide no. 3: coconut-papayapineapple-peanut multi-storey cropping model. Davao City, Philippines: Philippine Coconut Authority.

Philippine Coconut Authority. (2006a). Coconutbased farming system for increased productivity: vegetable intercropping under coconut palms. Davao City, Philippines: Philippine Coconut Authority.

Philippine Coconut Authority. (2006b). Coconut intercropping guide no. 5: coconut-root crops cropping model. Davao City, Philippines: Philippine Coconut Authority.

Philippine Coconut Authority. (2006c). Coconut intercropping guide no. 6: coconut-coffee (Robusta/Excelsa/Arabica) cropping model. Davao City, Philippines: Philippine Coconut Authority.

Philippine Coconut Authority. (2007). Coconut intercropping guide no. 7: coconut-cacao (cocoa) cropping model. Davao City, Philippines: Philippine Coconut Authority.

Philippine Council for Aquatic, Agriculture, Forestry and Natural Resources Research and Development. (n.d.) Okra production guide. Laguna, Philippines: Philippine Council for Aquatic, Agriculture, Forestry and Natural Resources Research and Development.

Philippine Council for Aquatic, Agriculture, Forestry and Natural Resources Research and Development. (2018). Agroforestry Information Network: Multistorey. 
Retrieved October 29, 2018, from http://www.pcaarrd.dost.gov.ph/home/mome ntum/afin/index

.php?option=com_content\&task=view\&id=4 $50 \&$ Itemid $=305$.

Philippine Statistics Authority. (2016a). Major fruit crops quarterly bulletin. Retrieved May 8, 2016, from http//www.psa.gov.ph.

Philippine Statistics Authority. (2016b). Updated costs of production of selected agricultural commodities 2013-2015. Retrieved November 20, 2018, from http//www.psa.gov.ph.

Philippine Statistics Authority. (2018). Bukidnon quickstat-January 2018. Retrieved November 13 , 2018 , from https://psa.gov.ph/content/bukidnonquickstat-january-2018.

Republic Act 10068. (2010). Organic Agriculture Act of 2010: an act providing for the development and promotion of organic agriculture in the Philippines and for other purposes. Retrieved November 26, 2018, from https://www.lawphil.net/statutes/repacts/ra20 10/ra_10068_2010.html.

Relacion, J.L. (2017). Growth and yield of welsh onion (Allium fistulosum L.) at varying rates of vermicast under coconut-cacao based cropping. (Unpublished undergraduate thesis), Central Mindanao University, Philippines.

Segarino, C.I. (2017). Growth and yield of upland kangkong (Ipomoea reptans) at varying rates of vermicast under coconut-cacao based cropping. (Unpublished undergraduate thesis). Central Mindanao University, Philippines.

Tabios, D.G.V. (2017). Growth and yield of pechay (Brassica rapa L.) at varying rates of vermicast under coconut-cacao based cropping. (Unpublished undergraduate thesis). Central Mindanao University, Philippines.

The Center for Ecogenetics and Environmental Health. (2013). Fast facts about health risks of pesticides in food. University of Washington. School of Public Health. Retrieved November 26, 2018, from https: agriculture\%20and $\% 20$ natural $\% 20$ resources $\% 20$ Kasetsart\%20University/full\%20paper/F F_Pesticides.pdf

Valleser, V.C. (2019). Growth and fruit physicochemical characteristics of 'MD-2' pineapple (Ananas comosus L.) at varying seedbed configurations. Pertanika Journal of Tropical Agricultural Science, 42(1), 377-386. 